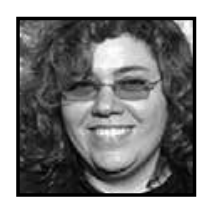

\title{
Myth, Metaphor, and Metacognition: Shaping Voice and Identity Through Poetry in Teacher Education
}

\author{
Amanda Nicole Gulla, City University of New York
}

\begin{abstract}
This article discusses the importance of teacher candidates writing poetry in their education methods classes in order to reflect upon and examine their beliefs about teaching and learning. Writing poetry in a teacher education context is also important because it prepares teachers to use these techniques with their own students. By writing poetry in the context of academic study, learners can see metaphorical connections between events and ideas. This stands in contrast to the idea put forth in the Common Core Standards that college and career readiness is best developed through reading and writing informational and argumentative texts.
\end{abstract}

ow does one learn to develop and enact all the complex layers of a teacher
identity? Where and how do we find within ourselves the raw materials to
mold into a teacher? Who is the self that teaches (Palmer, 1998) and how can that self effectively manage all of the moving parts of a functioning classroom, especially when faced with the increasingly daunting task of navigating complex standards and assessments? If teaching is considered by educational philosophers like Dewey (1934), Eisner (1994), and Greene (2001) and practitioners like Mitchell and Christenbury (2000) to be an art form, then is "the self that teaches" akin to what writers and other artists refer to as "voice?" Moreover, what difference could it make to students whether or not their teachers have the opportunity to express themselves creatively? 
These are the questions that inform our teaching methods courses in English Education in a large city university, teaching graduate students preparing to become certified to teach English grades 7-12. For the purpose of this article, these graduate students will be referred to as teacher candidates.

While a teacher's work is governed by a responsibility to serve students within some version of a socially constructed notion of "school," what kind of room does that leave for a teacher to weave his or her own unique creative vision into that professional role? When one attends meetings at schools about curriculum, professional development, or even special programs for enrichment, one seldom hears the word "creativity" at all. In fact, I have heard the word "creative" used dismissively, pejoratively by teachers and administrators who value a pedagogy based in uniformity and discipline. Maxine Greene, quoted in the NY Times (Arenson, 2001), says: "Imagination is given a very small place in the way people talk about learning today, but it is a way to go beyond, to break through boundaries." This is why we have woven into our methods classes multiple opportunities for teacher candidates to engage in creative writing and art making, as well as prolonged study of non-textual works of art including paintings, photographs, and performances in dance, music, and theater. Allowing teachers to explore their own creativity and imagination in methods classes broadens the nature of the questions they pose in relation to the curriculum, their students, and themselves. Kara, an eighth grade teacher in my Methods of Teaching Writing class, wrote in her final reflection paper:

I'm so deeply grateful that we got to spend time in this class writing poetry. It gave me a chance to use writing to explore what is going on in an interaction with a student, and it helped me see possibilities for getting my students truly invested in their own writing.

Whether or not this is intentional, The Common Core State Standards (CCSS) and their accompanying assessments, adopted by 45 out of 50 states in the United States as of this writing, have added considerable exigency to the sense that there is an overwhelming amount of information to be assimilated in preparation for teaching. This has left many teachers and administrators with the sense that there is little or no time for poetry or experimental writing. This impression might also have been reinforced by disparaging comments made by David Coleman, one of the authors of the English Language Arts standards, regarding the practice of having students write personal memoirs. Before a 2011 gathering of educators in Albany, New York, Coleman said: "As you grow up in this world, you realize people really don't give a shit about what you feel or what you think" (Ohanian, 2011). 
The CCSS strive for "career and college readiness" through an emphasis on reading "informational texts." This is widely interpreted to mean nonfiction, although a persuasive argument could be made that it would be difficult to find a text that does not contain information of some kind. Furthermore, the language of the CCSS states: "...the overwhelming focus of writing throughout high school should be on arguments and informative/explanatory texts" (2011). The CCSS calls for adopting the 2011 National Assessment of Educational Progress (NAEP) Framework for writing, which requires the distribution of student writing in the 12 th grade to be $40 \%$ to persuade, $40 \%$ to explain, and $20 \%$ to convey experience. For those of you keeping score, that is $0 \%$ to imagine, $0 \%$ to innovate, and $0 \%$ to experiment and play with language.

Even within the parameters of national learning standards there can still be room for inquiry, imagination, and creativity. If we want an education that helps students pursue self-motivated inquiry to acquire the skills of lifelong learners; if we want them to have access to multiple modalities of expression; then we need teachers who can teach these things. Teacher education courses have often included opportunities for candidates to experiment with multiple modalities of learning including the artistic and kinesthetic. These techniques are sometimes used in conjunction with exercises designed to help candidates develop understandings about principles of teaching and learning by exploring their own histories and beliefs. In my own methods classes we use the study of one or more works of art as a focal point for discussion and writing. In using Mary Whalen's portfolio of photographs of objects found in an attic called Household Artifacts (2011), we explore ways in which some artists have mined the mundane for symbolic meanings. We study this portfolio in conjunction with readings of Neruda's Ode to Common Things (1994) and Tim O'Brien's The Things They Carried (1990). Against the backdrop of this inquiry into various artists' storytelling through objects, the teacher candidates write their own narratives or poems centered on personal artifacts. In response to these experiences, one student wrote this on our class online discussion board:

I've never been exposed to this writing approach before, using objects to inspire. I feel like it is a very powerful and personal medium. When I was writing about my object, my necklace, which I certainly prized beforehand, aspects I hadn't even considered began to emerge. I think that was the biggest revelation. Through writing, we not only put our thoughts down on paper, but the writing process itself can breed new thoughts and ideas. (Online reflection, 2014)

The teacher candidates saw value in mining their own lives for stories to help them find their own voices as writers because it would help them become better teachers of writing. Here is another student's reflection on the discussion board: 
This is a great way to get students to create imagery in their writing. I have had students write short memoirs before, and I struggled with getting all of them to write in detail. I think having them choose an object that is/was significant to them would help, and they would produce better writing with a clear focus. (Online reflection, 2014)

School systems tend to regard arts programs with a kind of ambivalence. Few administrators would actually say that they do not value the arts, but in tight budgetary times they are often the first item to be cut. Davis (2008) quotes a school committee member:

Our students have so many demands on them from staying out of trouble to gaining the skills to be successful in the adult world. The important subjects in preparing students for such responsibility are reading, science and math. No frills. (p. 25)

Eisner has also observed that the arts are either implicitly or explicitly treated as a frill in relation to the school curriculum. In the traditional K-12 school, art is a discrete subject that students partake in once a week, if at all. It is rare in public schools that students beyond elementary school will have experiences with more than one art form, say visual art and music, in any given semester. Grades in art classes often do not count toward graduation credits, and students are quite aware of this. According to Eisner (2002):

Although elementary schools are generally supposed to provide programs in the arts, few thought-out and competently taught art programs exist at this level. Elementary school teachers have little background in the arts and, in general, are not well prepared to teach them.

At the secondary level, where there are art specialists, the arts are taught in about half of all secondary schools and only 20 percent of the school population enrolls for as little as 1 year. This neglect of the arts, compared with, say, the sciences, leaves students unable, by and large, to deal meaningfully with sophisticated forms of the serious arts. (p. 106)

Because many students come through American schools having had little exposure to the arts or opportunity for creative expression, teacher candidates who are products of this schooling need to spend time in methods courses immersed in encounters with works of art (Greene, 2001). Furthermore, the act of making art (in this case writing poetry) in response to art deepens and enriches understanding. Dewey (1934) speaks of the importance of an "esthetic apprenticeship" while Greene (2001) refers frequently 
to the need for learners to have art-making experiences in order to better understand the artist's process.

Using teacher candidates' responses to works of art to activate their imaginations and develop a degree of comfort with moving from imaginative ideas to creative expressions of their own helps them begin to find ways to facilitate their middle and high school students' creative development. When teacher candidates spend time with the process of writing poetry they are using language-the currency of the English classroom-as the medium with which to explore how their identities may shape them as teachers.

Snowber (Wiebe \& Snowber, 2011) suggests that the act of poetic inquiry, specifically writing autobiographical poems, "insists on a willingness to be vulnerable...from which we can profess a creative experience of educational practice" (p. 449).

The value of the willingness to channel one's vulnerability through the conduit of creativity is related to what Maxine Greene (1994) means when she says that she can try to achieve her "freedom in an expanded sphere" and "act-as teacher, as practitionerto transform...what alienates people from themselves" (p. 27). Namely, that when a teacher establishes a professional identity that allows her to enact a version of herself that is whole and authentic, that form of interaction tends to invite students to bring their authentic selves into the classroom as well.

Education methods courses are spaces in which teacher candidates learn to approximate various teaching practices including writing lesson plans, administering assessments, and presenting lessons. Because of the need to give candidates as much preparation as possible for their own (sometimes future, sometimes current) classrooms, there has always been a pragmatic emphasis on what we do in the classroom rather than why we do it (Applebee, 1998). This is understandable, but I would argue that it is equally important for teachers of all subjects to spend some time engaging in activities designed to uncover and articulate unexamined beliefs about teaching and learning and also about their own relationship to the material they are teaching.

Writers about writing as diverse as James Britton (1970) and Stephen King (2000) put forth the notion that the act of writing allows the thinker to see what it is that she knows and believes unfold before her on the page. It has been my experience that writing poetry in teaching methods courses is an effective way of having teacher candidates explore issues of identity. Anne McCrary Sullivan (2000) describes the relationships between poetry and educational inquiry to be "multiple, subtle and complex" (p. 220). 
The nature of poetry leads one to craft metaphors that capture and describe the essential core of an experience. In Ely's view, a poem: "encapsulates the essence of an event that many of us have lived in our own way at one time or another ... the intensity and the compression of poetry emphasizes the vividness of (a) moment" (Ely, Vinz, Downing, \& Anzul, 1997, p. 135).

Moreover, it is the practice of viewing and making art, and the immersion in poetic language, that establishes metaphorical thinking. This practice takes hold only after multiple encounters and experiences both responding to and making art. For Eisner (2002): "The ability to think metaphorically is not the outcome of a single occasion; it requires repeated opportunities to explore the poetic use of language, a use of language that generates meaning through indirection, allusion, and innuendo" (p. 12). This need exists not only for children, but also for their teachers. Many teachers' own school experiences did little to build comfort with using writing as a tool to develop thinking. Far too many school writing assignments are "dummy-run experienceswritten on demand, for a teacher to evaluate about a topic the writer didn't choose" (Mayher, 1990, p. 227). They exist for the sake of demonstrating knowledge, not exploring evolving understandings. Because of high stakes standardized tests that emphasize argumentative writing, it is virtually guaranteed that large numbers of students will have little or no opportunity for poetry or other forms of expressive writing in school. This represents a missed opportunity to develop broader world understandings through the ability to comprehend the ways in which art and literature reflect human experience. Our world, filtered through media, the arts, and our own senses, is understood through a web of interconnected metaphors.

Much has been written about the notion that we understand the world largely through metaphor (Lakoff \& Johnson, 1980; Geary, 2011). Metaphors serve the essential cognitive function of bridging from the familiar to the unknown by using descriptive imagery that allows learners to use their prior knowledge to understand new information.

To "train" the mind "to help you open your ears so that you can begin to hear metaphorically instead of concretely" (Campbell \& Moyers, 1988, p. 77) is to foster the ability to see beyond the literal, and to begin to understand the interconnectedness of human events across cultures, geography, and time through the web of metaphor.

Wherever possible, I attempt to plant the seeds of metaphorical thinking before our students become teacher candidates. I teach an undergraduate lecture course called "The Hero's Journey in Literature and the Arts" to students who are considering 
entering the education minor course sequence. In this course we read a number of texts by Joseph Campbell, including The Power of Myth (1988), in which he explained that myths may be understood metaphorically. An example of one such metaphorical phrase is "identifying the Christ within you" (p. 46). Having already established that Campbell considered the words "myth" and "religion" to be essentially synonymous, some of the more religious students protested vocally that their religion was literally true and to suggest otherwise was blasphemy. I had been arguing that accepting the premise that all myths (i.e., all religions) can be understood metaphorically means that all religions contained some truth within their common ideas. We discussed the seemingly uncanny recurrences across the globe of certain ideas, images, and symbols as evidence that all religions were as the branches of a single tree, the roots of which are expressions of the life cycle of earth and particularly of human life. It was a delicate space from which to conduct a class. In the end, the most vocal of the protesters wrote this in her final reflection:

Before this course I had never even considered another point of view. While I still hold the same beliefs I did before, I am forever changed in that now I am willing to listen to opinions and beliefs that may not agree with mine. I don't just listen, I actually think about them. (Student reflection paper, 2012)

For someone who may eventually become a teacher, the ability to consider another person's point of view can represent an enormous shift in practice. It can make the difference between being a teacher who "imposes inarticulateness" (Greene, 1995) upon his or her students, or "provokes learners to pose their own questions" (p. 11). The ability to consider another point of view is crucial to the development of critical thinking skills.

Our class discussion of myths and metaphors arose from a semester-long study of stories representing different versions of the hero's journey in literature, film, visual art, and popular music. We looked for the common threads in all of these stories and students used them as touchstones for writing their own creative works they shared with their classmates. It was the two-way exploration of metaphors, reading them in the works we studied and then writing them in their own stories that grounded the difficult discussions around religion. The community created by those shared experiences made it possible for that student to begin to listen in ways she never had before. Studying the connections between works of art and our own experiences opened the door to deeper understanding. 
An education that is richly infused with a variety of works of art exposes students to responses to human events that have taken place over the broad sweep of history. And writing poems in response to those works of art, if done thoughtfully, teaches young people not just how to express their feelings, but gets them to stand in the ever-flowing river of history, entering into conversations with all of the writers and artists who have come before them, commenting on the human experience. This is the promise of poetry that is rooted in an aesthetic encounter with a work of art. When we teach students how to deeply notice what an artist is doing and how she is doing it, we are getting at the essence of what that art is about. We are helping young people to understand that having a voice is not just about saying whatever is on your mind, it is about finding connections between your personal experiences and essential truths about life on earth. It allows us to recognize the metaphors in great works of art that speak to universal experience. By entering into dialogues with works of art that speak to aspects of the human experience, we are drawing from the well of mythology (Campbell, 1991). Once students begin to recognize the mythological archetypes that recur across time, cultures, and art forms, they can see their metaphorical significance in their own lives and in contemporary society. Once they have been awakened to the broader meaning of stories, they can begin to use them as another means of crafting an argument that goes beyond the limited scope of the Common Core.

It is easy to argue for a kind of skills emergency when it seems that so many students graduate from high school unprepared for the rigors of college-level reading and writing. By squeezing out the opportunity to interact with imaginative texts, we lose the opportunity to teach the lessons that are best learned from fiction and poetry as well as the study of other art forms. As the poet William Carlos Williams (1962) said: "It is difficult to get the news from poems, yet men die miserably every day for lack of what is found there" (p. 161). More to the point, by focusing narrowly on a limited range of types of writing, we actually deprive learners of strategies and broader understandings that could help them achieve the goal of writing clearly and persuasively.

Surely no one would argue against the importance of developing facility with academic reading and writing. However, by failing to ensure that students have ample opportunities to read and write poetry and fiction, in addition to reading informational texts and writing expository essays, we miss opportunities to teach students the almost endless variety of possible approaches to constructing and conveying arguments. Conventional wisdom suggests that if we want people to acquire the skill of writing a cogent, persuasive, and factually supported argument, we want to teach them the steps and then have them practice the skill of writing argument papers repeatedly. This provides a singular, and quite literal approach in that it ignores a multitude of 
possible forms of constructing an argument metaphorically. Similarly, a privileging of "informational texts" over fiction and poetry leaves out all the ways in which literature can hold up a mirror that allows us to understand some fundamental facet of the human experience through metaphor.

As graduate students, new and pre-service teachers have abundant opportunities to engage in expository writing about pedagogical theories or in response to literary texts. Such writing, intended to convey formal ideas, is what Britton (1970) refers to as "transactional." Graduate students in education also often have teaching and learning journals that they may share with their instructor or with a group in online formats. These fit into the category Britton calls "expressive writing." Such writing may remain in its existing form, or may be revised into formal expository or transactional writing. These types of writing represent only two of the three types that Britton describes. A third type, rarely engaged in teacher education contexts, is "poetic writing." For Britton, transactional writing "may elicit the statement of other views, of counterarguments and corroborations or modifications ... Poetic writing, on the other hand, demands a 'sharer,' an audience that does not interrupt" (p. 175). Britton explains that a piece of writing may start out as expressive and may move through revision to either transactional or poetic writing. It is not only the poetic writing itself that teachers rarely have the opportunity to do in a formal setting, but also the kind of response poetic writing tends to engender that they rarely experience. Britton explains that when a piece of writing moves from expressive to poetic, it "reaches a wider audience ... by heightening or intensifying the implicit" (p. 177). In other words, poetry demands that a reader or listener respond to the world the writer has created as a whole, rather than piecemeal as one might a piece of transactional writing.

This process of intensifying the implicit in writing poetry allows learners to make sense of the world through writing. As Murray (1978) explains, "I believe increasingly that the process of discovery, of using language to find out what you're going to say, is a key part of the writing process" (p. 91). The poet Alan Dugan (1978) said: "When I'm successful, I find the poem will come out saying something that I didn't previously know, believe, or had intellectually agreed with" (p. 101).

The spare language and imagery of poetry can help both the writer and the reader see the essence of an idea or experience as it is expressed in writing. By capturing experiences in poetic form we transform those experiences from the particulars of our lives to the universal. This is what metaphors do-they allow others to have access to that which is universal within our very specific and disparate lives. In the process of transforming lived experience to writing, we carefully choose words for just the 
right meaning, sound, and rhythm to convey our message. Like Dugan, I have often discovered meanings that had previously been hidden to me through the process of crafting a poem, whether it be a slow, methodical process or the occasional surprise of the poem that appears to spring full grown from the writer's head.

When I assign poetry in methods classes, teacher candidates often report continuing the practice on their own as a way of helping them work through complex and evolving ideas and relationships in the context of their teaching. The value of poetry as a tool is repeatedly confirmed when teacher candidates report writing poems beyond their class assignments, spending their free time writing poems about encounters with students, administrators, or even family members as a way of both describing and making sense of them. An excerpt from a poem by a first year teacher in my Methods of Teaching Writing in Middle and High School course clearly shows her working out her feelings about school:

\author{
I work on swollen feet \\ with calloused hands, \\ crack skulls to the beat of foreign phrases \\ so pardon me if my sympathies are \\ reserved for the young.
}

Later the author of this poem said, "I needed to write that in order to realize how much I really do align myself with my students." Reading this excerpt of her poem, however, one cannot help but see the ambivalence alongside her sense of alignment. Her "sympathies may be reserved" for her students, but the image of cracking skulls suggests that sometimes those sympathies are tested. The poem created a safe space for her to express conflicting feelings and come through that by expressing a value that was important to her sense of self as a teacher.

As teachers develop the practice of writing to develop their own thinking, they become more comfortable with teaching this strategy to their students. The practice of having their students write poems to situate themselves in relation to their studies can also stand the teacher candidates in good stead in their own classrooms, as they introduce new content by having students begin with focused writing that may lead to poetry or other forms of writing related to the subject matter. Even for teachers of very young children, this initial inquiry can be pursued in the form of drawing and writing assisted by a teacher or a peer. 
Writing helps students become invested in subject matter, build a frame of reference, and form questions to guide their reading and learning (Bean, 2001). Poetry in particular forges a connection between the learner and the subject matter, as writing poetry is seen as an invitation to view the subject matter as human and personal. From high school students in an automotive shop class writing lighthearted poems personifying brake fluid as it flows through an engine (Darvin, 2001) to eighth graders writing poems in the voices of slain Civil War soldiers in their American history class (Gulla, 2009), the close attention required to give voice to another is itself a form of inquiry. Students' learning is propelled by their own curiosity.

This is how Sue, a middle school Social Studies teacher, and I responded to the problem of having a single school year to teach all of American history from the Civil War to the present. She had been in my Writing Methods course (even though it was an English Education methods course, students did sometimes cross programs to take additional methods courses), in which I had introduced the strategy of "text-on-text conversations" (Daniels \& Daniels, 2013). There are many variations on the activity, but it essentially consists of grouping students together to read a short, challenging text and conducting a discussion of the text by writing comments and questions in the margins and then responding to each other's marginalia.

After Sue graduated she asked for help incorporating writing into her Social Studies classes. We approached the task by asking how we could teach this massive amount of material in a way that students would become invested in the events they were learning about. To this end, we planned for me to pay several visits to her classroom so that we could co-teach her students.

Thinking about how information in Social Studies (like most other academic subjects) is introduced almost exclusively via the written word, we thought it might be effective to use visual images to introduce an idea before they read about it, so we adapted the text-on-text conversation to use pictures to generate the written conversations. I gathered copies of Matthew Brady's iconic Civil War battlefield photographs and placed each one in the center of a large sheet of newsprint. Organizing the class into groups of four, each group was assigned to write around the margins of their photograph. At first I instructed them to simply label what they saw in the picture. Then I asked them to analyze and question, speculating as to what they thought might be going on in the scene. Finally, they were each to choose a point of view from within the photograph and write a poem. Here is one of the students' poems: 
I am the sky

looking down upon the blood-soaked earth.

Dead soldiers' limbs entangled,

brother next to brother.

Impossible to tell who is on what side.

But I, the sky, remember the whip

striking the backs of slaves.

My sigh is the wind and my tears are the rain

as I look down upon another day of bloodshed.

The student who wrote this poem spent time looking and thinking deeply about the images in the photograph and what they meant. He connected the bloody battle scene to the acts of violence that led to the war, and expressed his own feelings as personified by the omniscient sky. This was a powerful example of teaching history without a textbook, using primary source documents and student-driven inquiry. Later, we used Picasso's Guernica to teach about the Spanish Civil War. Students wrote passionately about the images in that painting — the screaming horse, the bereft mother holding her deceased baby, and the mysterious light bulb in the middle of it all. The use of creative writing in response to vivid visual imagery sparked discussions about war writ large and its place in human history. Again, it was a gathering of ideas around metaphors that helped students not just to learn about history, but also to understand it. Such discussions do not usually come from memorizing names, dates, and battles.

The conversation about whether or not it is important for teachers or students to write poetry is connected to where one stands on the issue of whether or not anyone should expect the world to care what we think or feel. Perhaps Mr. Coleman has a point, if he means that students learn little from writing memoirs that are devoid of reflections or revelations, or are written in language that is colloquial and childish. If this is his point, then his standards are pitifully low. There is nothing as meaningful, as "astonishingly precise" (Geary, 2011) as a metaphor. By encouraging metaphorical thinking through encounters with the arts and through writing poetry, we give these teacher candidates the tools to understand universal connections between stories and between lives, and to pass these experiences on to their own students. 


\section{References}

Applebee, A. (1998). The enterprise we are part of: Learning to teach in The Word for Teaching is Learning: Essays for James Britton: M. Lightfoot and N. Martin (Eds.). London: Heinemann, Ltd.

Arenson, K. (2001, October 3). One philosopher's alchemy: Teaching as romance. NY Times. Retrieved from: http://www.nytimes. com/2001/10/03/nyregion/one-philoso pher-s-alchemy-teaching-as-romance.html

Bean, J. (2001). Engaging ideas: Guide to integrating writing, critical thinking, and active learning in the classroom. San Francisco: Jossey-Bass.

Britton, J. (1970/1992). Language and learning (2nd edition). Portsmouth, NH: Boynton Cook.

Campbell, J., \& Moyers, B. (1988). The power of myth. Flowers, B. (Ed.) New York: Doubleday.

Campbell, J. (1991). Reflection on the art of living: A Joseph Campbell companion. D. Osbon (Ed.). New York: HarperCollins.

Coleman, D. et al. (2011). Common Core State Standards in ELA. Retrieved from: https:// www.engageny.org/resource/new-yorkstate-p-12-common-core-learning-stan dards.

Daniels, H., \& Daniels, E. (2013). The best-kept teaching secret: How written conversations engage kids, activate learning, grow fluent writers. Portsmouth, NH: Heinemann.

Darvin, J. (2001). On filling out forms: A more powerful version of workplace literacy. English Journal, 91(2), 35-40.

Davis, J.H. (2008). Why our schools need the arts. New York: Teachers College Press.

Dewey, J. (1934). Art as experience. New York: Penguin Press.

Dugan, A. as cited in Murray, D. (1978). Internal revision: A process of discovery. In C. R. Cooper and L. Odell (Eds.), Research on composing: Points of departure. (pp. 85-103). Urbana, IL: National Council of Teachers of English.
Eisner, E. (1994). Cognition and curriculum reconsidered (2nd edition). New York: Teachers College Press.

Eisner, E. (2002). The arts and the creation of mind. New Haven, CT: Yale University Press.

Ely, M., Vinz, R., Downing, M., \& Anzul, M. (1997). On writing qualitative research: Living by words. London: The Falmer Press.

Geary, J. (2011). I is an other: The secret life of metaphor and how it shapes the way we see the world. New York: HarperCollins.

Greene, M. (1994). Teaching for openings: Pedagogy as dialectic. Pedagogy in the age of politics: Writing and reading (in) the academy. P. Sullivan \& D. Qualley (Eds.). Urbana, IL: National Council of Teachers of English.

Greene, M. (1995). Releasing the imagination: Essays on education, the arts and social change. San Francisco: Jossey-Bass.

Greene, M. (2001). Variations on a blue guitar: The Lincoln Center Institute lectures on aesthetic education. New York: Teachers College Press.

Gulla, A. (2009). Changing things as they are: Promoting social justice through encounters with the arts. University of Pennsylvania. Perspectives on Urban Education, 6(2), 51-57.

King, S. (2000). On writing: A memoir of the craft. New York: Scribner

Lakoff, G., \& Johnson, M. (1980). Metaphors we live by. Chicago: University of Chicago Press.

Mayher, J. (1990). Uncommon sense: Theoretical practice in language education. Portsmouth, $\mathrm{NH}$ : Heinemann.

Mitchell, D., \& Christenbury, L. (2000). Both art and craft: Teaching ideas that spark learning. Urbana, IL: National Council of Teachers of English.

Murray, D. (1978). Internal revision: A process of discovery. In C. R. Cooper \& L. Odell (Eds.), Research on composing: Points of departure (pp. 85-103). Urbana, IL: National Council of Teachers of English.

Neruda, P. (1994). Odes to common things. New York: Hachette. 
O'Brien, T. (1990). The things they carried. New York: Houghton Mifflin.

Ohanian, S. (2011). The crocodile in the common core standards. Retrieved from: http:// susanohanian.org/show_commentaries. php?id=984.

Palmer, P. (1998). The courage to teach: Exploring the inner landscape of a teacher's life. San Francisco: Jossey-Bass.

Sullivan, A.M. (2000). Notes from a marine biologist's daughter: On the art and science of paying attention. Harvard Education Review, 70(2), 211-227.
Whalen, M. (2011). Household Artifacts. Retrieved from: http://www.marywhalen. com/MW_DreamWeaver/marywhalen_ currentwork.html

Wiebe, S., \& Snowber, C. (2011). En/lived vulnere: A poetic of im/possible pedagogies. In S. Thomas, A. Cole, and S. Stewart (Eds.), The art of poetic inquiry. Big Tancook Island, Nova Scotia: Backalong Books.

Williams, W. C. (1962). Asphodel, that greeny flower in Pictures from Brughel and other poems. New York: New Directions Books.

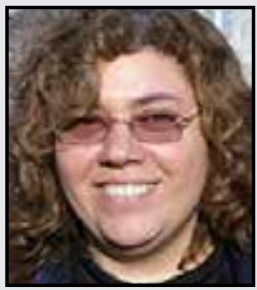

Amanda Nicole Gulla is an Associate Professor of English Education at Lehman College of the City University of New York and the Professional Development Liaison for middle and high schools. She is on the advisory board of the Maxine Greene Center for Aesthetic Education and the Social Imagination, and co-edits the center's newsletter. Her research and publications include the topics of aesthetic education, poetic inquiry, and the formation of teacher identity. She is also a poet whose work has appeared in several literary and scholarly journals. She is the author of a poetry chapbook, A Banner Year for Apples (Post Traumatic Press, 2010). 